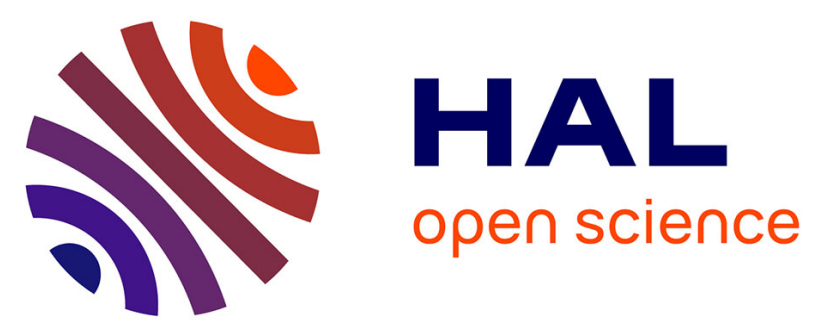

\title{
The Archaeology of the Earliest Monasteries in Italy and France (Second half of the Fourth Century to the Eighth Century)
}

\author{
E. Destefanis, Sébastien Bully
}

\section{- To cite this version:}

E. Destefanis, Sébastien Bully. The Archaeology of the Earliest Monasteries in Italy and France (Second half of the Fourth Century to the Eighth Century). Beach A.-I., Cochelin I. The Cambridge History of Medieval Monasticism in the Latin West. Origines to the Eleventh Century, Cambridge University Press, pp.232-257, 2020. halshs-03079199

\section{HAL Id: halshs-03079199 \\ https://shs.hal.science/halshs-03079199}

Submitted on 11 Feb 2022

HAL is a multi-disciplinary open access archive for the deposit and dissemination of scientific research documents, whether they are published or not. The documents may come from teaching and research institutions in France or abroad, or from public or private research centers.
L'archive ouverte pluridisciplinaire HAL, est destinée au dépôt et à la diffusion de documents scientifiques de niveau recherche, publiés ou non, émanant des établissements d'enseignement et de recherche français ou étrangers, des laboratoires publics ou privés. 


\title{
The Archaeology of the Earliest Monasteries in Italy and France $\left(5^{\text {th }}-8^{\text {th }}\right.$ c. $)$. State of the question.
}

\author{
Eleonora DESTEFANIS, Sébastien BULLY ${ }^{1}$
}

Late Antique and Early Medieval monasticism emerged in many different forms, both in institutional terms and in the organisation of the communities. This plurality of form had a significant influence on the physical structures of the monasteries, although our knowledge is somewhat limited by the scarcity of archaeological remains. In both Italy and France, archaeological research has traditionally been focussed on the sacred buildings of these sites, at the expense of the quotidian structures. Furthermore, aside from the few rare examples, the panorama of sites for which we have evidence for the earliest monasteries remains incomplete.

In addition to these issues there are the problems related to the interpretation of terms used in written sources, given the fact that certain terms can have multiple meanings. ${ }^{2}$ Monasterium, for example, can refer to the monastic institution as well as the spaces of the monastic community, however, it can also take on very different meanings. In the region of Ravenna, for example, it refers to an oratory or a chapel, while in other areas it can mean a private church, reserved for the personal use of the founder and their family. ${ }^{3}$ Often it can be used to refer to the dependencies of a monastery without, however, necessarily implying the presence of a religious community. ${ }^{4}$ Moreover, the use of the term abbas in the earliest period, both in Italy and in France, cannot be taken as a sure sign of an organised religious community. ${ }^{5}$ In reality, abbas may simply be used to describe a charismatic, 'venerable', individual who is not necessarily linked to an organised religious community. In other cases, the term covers a range of meanings, well documented from the $6^{\text {th }}$ century onwards, to describe individuals who hold eminent positions within a religious community, occupying cells linked to sanctuaries for example, but which cannot be defined as monasteries. ${ }^{6}$

In spite of all of this, in Italy in particular, a number of recent overviews have highlighted the important advances made over the last few decades, with a notable increase in the number of

\footnotetext{
${ }^{1}$ Translation by Emmet Marron, Newcastle University.

${ }^{2}$ On the topic of terminology see : L'origine des sites monastiques : confrontation entre la terminologie des sources textuelles et les données archéologiques, S. Bully et Ch. Sapin (eds.), Actes des 4èmes journées d'études monastiques, Baume-les-Messieurs, 4-5 septembre 2014, Bulletin du centre d'études médiévales d'Auxerre Bulletin du centre d'études médiévales d'Auxerre, BUCEMA Hors Série 10, Auxerre, URL : https://cem.revues.org/14463.

${ }^{3}$ G. Cantino Wataghin, "Monasteri di età longobarda: spunti per una ricerca”, Corsi di Cultura sull'Arte Ravennate e Bizantina, 36, 1989, 76.

${ }^{4}$ F. Marazzi, Le città dei monaci. Storia degli spazi che avvicinano a Dio, Milano: Jaka Book, 2015, 162.

${ }^{5}$ G. Cantino Wataghin, «Monasteri in Piemonte dalla tarda antichità al medioevo», in L. Mercando, E. Micheletto (eds.) Archeologia in Piemonte, III, Il medioevo, Torino: Allemandi, 1998, 168-169.

${ }^{6}$ L. Pietri, «Les abbés de basilique dans la Gaule du VI siècle», Revue d'Histoire de l'Église de France, 69, 182, 1983, 5-28; H. Noizet, «Les basiliques martyriales au VI et au début du VII ${ }^{\mathrm{e}}$ siècle», Revue d'Histoire de l'Église de France, $87,219,2001,329-355$.
} 
sites excavated. ${ }^{7}$ The same can be said for France, where the past 20 years has seen an increase in archaeological research on the earliest and most well-known sites, through a greater level of excavation and a reappraisal of older interventions. ${ }^{8}$ As a result of such recent work, this article will argue that, contrary to the common motif that appears in the majority of hagiographical treatments of a retreat into the 'desert', it is becoming increasingly clear that the choice of location for the earliest monasteries was much more tied into contemporary political machinations. Thus we find the reuse of earlier buildings (villae) and pre-existing religious sites (sanctuaries, mausoleums, martyria), or sites that are strategic in terms of communication or the exploitation of natural resources (castra, route-way stations, maritime stop-off points), not to mention those established in an urban setting (episcopal and aristocratic foundations). However, while the advance in research has allowed for a greater understanding of the contexts in which the earliest foundations were established, we still know very little about the spatial organisation of these sites for the period between Late Antiquity and the Early Medieval period. This is, in part, due to the great variety in form, which will be made clear below. The written sources and the limited archaeological record reveal the lack of a standardised organisation; it can be anything from a group of cells - wooden cabins or caves - to more elaborate buildings. We see ex-nibilo constructions and the reuse of Gallo-Roman buildings, in the midst of which there may be one or more churches, which are the one consistent reference of the monastic rules. ${ }^{9}$ However, the various monastic rules and hagiographical treatments make sporadic reference to other buildings linked to monastic life; enclosures, gates/gatehouses, guesthouses, refectories, kitchens, cellars, dormitories (from the $6^{\text {th }}$ century onwards), workshops, infirmaries, baths, stores, ovens, mills etc. The enclosure, in contrast to its importance in defining monastic space, is only mentioned in a few texts.

\footnotetext{
${ }^{7}$ Among the large body of recent research on the subject the following afford a particular level of attention to the written sources : F. De Rubeis and F. Marazzi (eds.), Monasteri in Europa occidentale (secoli VIII-XI): topografia e strutture, Proceedings of the International Conference (Castel San Vincenzo, 23-26 settembre 2004), Roma: Viella, 2008; E. Destefanis, «Archeologia dei monasteri altomedievali tra acquisizioni raggiunte e nuove prospettive di ricerca", Post-Classical Archaeologies, 1 (2011), 349-382; F. Marazzi, Le città dei monaci. Storia degli spazi che avvicinano a Dio, Milano: Jaca Book, 2014; Colloques De re monastica publiés par la Fondazione CISAM de Spolète: I, L. Ermini Pani (ed.), Committenza, scelte insediative e organizzazione patrimoniale nel medioevo (Tergu, 15-17 septembre 2006), 2007; II, M. C. Somma (ed.), Cantieri e maestranze nell'Italia medievale (Chieti-San Salvo, 16-18 mai 2008), 2010; III, L. Ermini Pani (ed.), Le Valli dei monaci (Roma-Subiaco, 17-19 mai 2010), 2012; IV, L. Ermini Pani (ed.), Teoria e pratica del lavoro nel monachesimo altomedievale (Roma-Subiaco, 7-9 juin 2013), 2015; V, Gli spazi della vita comunitaria (Roma-Subiaco, 8-10 juin 2015), 2016; O. Delouis, M. Mossakowska-Gaubert (eds.), La vie quotidienne des moines en Orient et en Occident ( $\mathrm{IV}^{\mathrm{e}}-\mathrm{VI}^{e}$ siècle), Le Caire: Institut Français d'Archéologie Orientale et Athènes : École Française d'Athènes, 2015. In relation to Late Antique monasticism in Italy, see: G. Jenal, Italia ascetica atque monastica. Das Asketen- und Mönchtum in Italien von den Anfängen bis zur Zeit der Langobarden (ca. 150/250-604), Stuttgart, 1995; G. Cantino Wataghin, «Moines et monastères en Italie à l'arrivée de Colomban: quelques données entre archéologie et histoire", Bulletin du Centre d'études Médiévales d'Auxerre, 20.2, 2016 (http://cem.revues.org/14521). See also the recent treatment by F.R. Stasolla, Il monachesimo in Italia dalle origini a Gregorio Magno: modalità insediative, architetture, organizzazione topografica e spaziale, à la LXIV Settimana di Studio (Spoleto, 31 mars-6 avril 2016), Monachesimi d'Oriente e d'Occidente nell'Alto Medioevo. ${ }^{8}$ Ch. Sapin, "L'archéologie des premiers monastères en France ( $V^{e}$-déb. XI ${ }^{e}$ s.), un état des recherches ", F. De Rubeis and F. Marazzi (eds.), Monasteri in Europa..., op. cit., p. 83-102 ; C. Treffort, « Des mots aux choses : traces de la vie quotidienne des moines en Gaule avant l'an mil ", in La vie quotidienne des moines... op. cit., p. 359-370.

${ }^{9} \mathrm{~S}$. Uggé, "Lieux, espaces et topographie des monastères de l'Antiquité tardive et du haut Moyen Âge : réflexions à propos des règles monastiques ", in Monastères et espace social. Genèse et transformations d'un système de lieux dans l'Occident médiéval, M. Lauwers (ed.), Collection d'études médiévales de Nice, vol. 16, Turnhout: Brepols, 2015, p. $15-4$.
} 
Aside from the literary sources, however, what can archaeology tell us about the 'structural reality' of the earliest monasteries? In order to answer this question, the following is intended as a general outline of the situation in Italy and France from a comparative perspective.

\section{Italy}

\section{Late Antiquity}

Already around the middle of the fourth century and the following decades, the earliest forms of community organisation began to take shape, marked by the pursuit of communal prayer and life, attested to in episcopal contexts and closely linked to charismatic bishops such as Eusebius of Vercelli and Ambrose of Milan. ${ }^{10}$ Although they are often referenced as some of the earliest expressions of Western coenobitic monasticism, in reality these experiences remain something of an anomaly when compared to later developments, given the fact that the participants who gathered around the bishop were clerics who, while living a life of prayer in commune, chastity and concordia (a keystone of their existence), were also occupied with the carrying out of their liturgical and priestly duties, as documented in the case of Vercelli.

Late Antique ascetic practice developed along two other lines. On the one hand, eremitism spread in its various forms throughout central Italy and the Islands (from the Tuscan Archipelago to the islands of Liguria) ${ }^{11}$, as well as in Northern Italy. Jerome had also mentioned the Dalmatian islands in the Adriatic Sea as places of ascetic experiences. ${ }^{12}$ On the other hand, some ascetic practices evolved in an essentially domestic environment, well illustrated in the Roman context by the letters of Jerome, which document the transformation of sumptuous dwellings into places of ascetic life by members of the aristocracy, particularly women. Perhaps understandably, no material remains of this phenomenon have been uncovered to date, since it took very little to transform the former dwellings into places of solitary life ${ }^{13}$.

In the wake of these experiences, but in a manner more clearly oriented towards organised community life, one can add the references to later monasteries documented in the city of Rome during the course of the sixth century. One illustrative example is the cenobium of St. Andrea "that is named Scaurus' slope" (qui appellatur clivum Scauri), founded by Gregory the

\footnotetext{
${ }^{10}$ Further, similar examples in the Italian context can be found in L. Dattrino, «Il cenobio clericale di Eusebio», in E. dal Covolo and R. Uglione and G. M. Vian (eds.), Eusebio di Vercelli e il suo tempo, Roma: Las, 1997, 341, footnote 9 .

${ }^{11}$ For central Italy see many contributions on the subject in L. Ermini Pani (ed.), Le valli dei monaci, Proceedings of the International Conference (Roma-Subiaco, 17-19 Mai 2010), II, Spoleto: Fondazione CISAM, 2012; for the Thyrrenian islands: R. BELCARI, «Monachesimo insulare tirrenico. Fonti documentarie e attestazioni materiali a Montecristo e nelle altre isole dell'arcipelago toscano", Hortus Artium Medievalium, 19 (2013), 79-97; D. Istria and $\mathrm{Ph}$. Pergola, «Moines et monastères dans les îles des mers Ligure et Thyrrénienne (Corse, Sardaigne, archipel toscan et archipel ligure)", Ibid., 73-78.

${ }^{12}$ For the monasticism in the islands see now: R. Martorelli, A. Piras, P.G. Spanu (eds.), Isole e terraferma nel primo cristianesimo. Identità locale ed interscambi culturali, religiosi e produttivi, Proceedings of the XI Congresso Nazionale di Archeologia Cristiana (Cagliari-Sant'Antioco, 23-27 September 2014), Cagliari: PFTS University Press, and notably the essays: F. Marazzi, «Le "isole" di Girolamo. Visioni sullo spazio dell'ascesi fra Roma e l'Italia alla fine del IV secolo», 605-614; M.C. Somma, «Sviluppo e prime manifestazioni del monachesimo tra terraferma e isole: il contesto italiano», 615-630; F.R. Stasolla, «I monasteri tra isole e terraferma all’età di Gregorio Magno», 631-643.

${ }^{13}$ See D. Brooks Hedstrom and H. Dey in this volume.
} 
Great on his property between 575 and 581 . The sources, and in particular his Dialogues, paint a picture of a composite material reality, that included some significant modifications made to the sumptuous Late Antique residence: in addition to the indispensible oratorium, the cenobium possessed a cemetery and an infirmary (infirmorum domus) ${ }^{14}$ as well as, according to John the Deacon's biography of Gregory (second half of the ninth century), various areas connected to everyday life such as a cellar (fratrum cellarium), stables for the horses, and the triclinium (a reception room of the previous domus) where the monks found respite during the hottest hours of the day ${ }^{15}$. At the same time, he also mentions at this point two oratoria, consecrated to Saint Mary and Saint Barbara and an atrium with a nymphaeum and the painted portraits of Gregory himself and his parents.

In his letters, moreover, Gregory provides proof of the dissemination of monasticism, above all throughout central and southern Italy $^{16}$. He evokes several organized communities, most located in the towns and strictly connected with the local episcopal authority, well integrated within their social and economic contexts. One of the most interesting aspects is the widespread female presence: women belonging to the highest social classes frequently appear as members of these religious communities and as foundresses. In the Roman context, early medieval structures have recently been brought to light in the area of Largo Argentina (in the area of the Campus Martius); they have been identified as the monasterium Boethianum, belonging to the family of Boethius. According to Riccardo Santangeli Valenzani, during the first half of the sixth century, a complex was installed in the abandoned temple area: Temple A was converted into a consecrated building to serve the religious community, whose members were most likely lodged in cells arranged along the rear of the temple, while the area in front of this would have been converted into a vegetable garden. On the opposite side of the complex, a rectangular building possibly served as a refectory (although the fact that it opened onto the adjacent street could lead us to think that it may have been a reception room) and, not far from this, a smaller building has been identified as the cellarium of the monastery. All of these structures lie within the enclosure that had previously defined the temple area, the entrances to which were now all closed off (with the sole exception of a small passageway maintained as the entrance to the monastic complex), in order to create a clear separation between the internal and external space, reflecting the need for a distinction from the surrounding world ${ }^{17}$. Still in Rome, one must also include the so-called "basilican monasteries" that, from the fifth century onwards,

\footnotetext{
${ }^{14}$ Gregorii Magni, Dialogi, III, 35 and IV, 49, in Gregorio Magno, Storie di santi e di diavoli (Dialoghi), latin texte edition and It. Transl. by M. Simonetti, critical edition by S. Pricoco, II, 145-147 and 320-323.

${ }^{15}$ Iohannes Diaconus, Sancti Gregori Magni Vita, I, $83-84$ and 89 in PL, 75, col. 229-230 and 234. See also: L. Pani Ermini, "Testimonianze archeologiche di monasteri a Roma nell'alto medioevo», Archivio della Società Romana di Storia Patria, 104 1981, 35-39.

${ }^{16} \mathrm{~A}$. de Vogüé, «Le monachisme vu par Grégoire le Grand», in C. Leonardi (ed.), Gregorio Magno e le origini dell'Europa. Proceedings of the International Conference (Florence, 13-17 Mai 2006), Firenze: SISMEL - edizioni del Galluzzo, 2014, 159-170.

17 R. Santangeli Valenzani, «Tra la Porticus Minucia e il Calcarario. L'area sacra di Largo Argentina nell'altomedioevo", Archeologia Medievale, 21 (1994), 57-98.
} 
sprung up to serve the basilicas of the martyrs in the suburban areas, with the aim of performing official duties and of providing both material and spiritual assistance to pilgrims. ${ }^{18}$

The Roman panorama represents, thus, quite a mixed context, with complexes made up of buildings that served complementary functions. This impression is further strengthened and confirmed by the monastic rules of sixth-century central Italy (the Rule of the Master and $R B^{19}$ ), which make numerous mentions of structural components. Some of these elements have been associated, for instance, with archaeological material found in the complex uncovered near Alatri and identified-with the monastery mentioned by Gregory the Great ${ }^{20}$ as located in the region called Campania (in Campaniae partibus). In this context, a surrounding wall with a single entrance encloses distinctive areas, including a vegetable garden, a cemetery, a two storied rectangular building which have been identified as the dormitory and refectory, as well as religious structure and service buildings ${ }^{21}$. The identification, however, of this complex with a monastery, as well as its chronology, is very problematic ${ }^{22}$, also considering that written sources about the site are very late.

A clearer image of monastic organisation comes from Vivarium, the monastery founded by Cassiodorus, close to Squillace, on the Ionian coast of Calabria. Beyond the literary focus and the clearly symbolic register of the well known description of the monastery written by Cassiodorus himself - in which the coenobium is presented as a form of Eden, a paradisiacal prefiguration also reflected in the landscape, full of water and rich gardens $s^{23}-$ a certain amount of detail is paid in the text to the physical surroundings, most notably in relation to the hydraulic infrastructure as well as references to the flow of visitors (foreigners and poors: peregrini and egentes) and the services that they necessitated in the monastery. These references are, moreover, completely compatible with the excellent roadside position of the site, which was easily reached and well incorporated into the main road system of the region, not far from the statio of Scilatio or Scilacio, mentioned in both the Itinerarium Antonini and the Tabula Peutingeriana. The site of Vivarium is generally identified in the present days with an ecclesiastical sixth-century (and beyond) site excavated on the ridge near Stalettì (eastern coast of Calabria), although some scholars keep having doubts about this proposal: the most notable feature in this place is the cult building, a single nave church, probably built at the time of the founding of the coenobium, which reuses a triconch structure (with a plan in the form of a trefoil) as its choir. According to the most recent interpretations, this structure may have originally been a mausoleum, belonging to the pre-existing villa, prior to being readapted to serve the monastic community. Adjacent to

\footnotetext{
${ }^{18}$ A. M. Giuntella, "I monasteri», in L. Pani Ermini (ed.), Christiana loca. Lo spazio cristiano nella Roma del primo millennio, Catalogue of the Exhibition (Roma, 5 September-17 November 2000), Roma: Palombi, 2000, 177-179.

${ }^{19}$ Uggé, Lieux, espaces et topographie.

${ }^{20}$ Gregorius papa, Dialogi, II, c. 35, M. Simonetti (ed.), Storie di santi e di diavoli (Dialoghi), I, Milano: Fondazione Lorenzo Valla, 2005, 207.

${ }^{21}$ E. Fentress, "The sixth-century abbey", in E. Fentress, C.J. Goodson, M.L. Laird, S.C. Leone (eds.), Walls and memory. The abbey of San Sebastiano at Alatri (Lazio) from Late Roman Monastery to Renaissance Villa and Beyond, Turhnout: Brepols, 2005, 33-70.

${ }^{22}$ R. Hodges, «Making memory into history? A re-interpretation of San Sebastiano at Alatri», Journal of Roman Archaeology, 20/2 (2007), 705-711 and now Cantino Wataghin, «Moines et monastères en Italie».

${ }^{23}$ Cassiodorus, Institutiones, I, c. 29 (de positione monasterii Vivariensis sive Castellensis), ed. R.A.B. Mynors, Oxford: Claredon, 1937, p. 73. See also M. Lauwers in this volume.
} 
the triconch, on the southern side, a small room was placed that housed a sarcophagus datable to the second half of the sixth century, which during the course of the Early Medieval period became the focus of religious devotion, as documented in the inscriptions carved on the cover $\operatorname{slab}^{24}$.

\section{The Lombard Period}

Into this heterogeneous context, albeit at a time when some characteristics were becoming more well defined, came the Lombards in the final decades of the sixth century. The negative impact of these invaders, it must be said, has been significantly revised by recent studies $^{25}$. Indeed, just a few short decades after their migration into the Italian peninsula, at the start of the seventh century, the Lombard monarchy were to become the central protagonist of one of the most notable events in the history of Italian monasticism: the foundation of the monastery of Bobbio. This came about due to joint initiative of King Agilulf and Saint Columbanus, who at that point had reached the end of the long peregrinatio that took him all the way across Europe from his native Ireland ${ }^{26}$. In the Vita of the saint and his disciples, written around 640 A.D., Columbanus' biographer, Jonas of Susa, himself a monk at Bobbio, describes the place chosen upon the community's arrival as wild and dominated by dense forest (in solitudine ruribus Appenninis) ${ }^{27}$, thus conforming to the well known hagiographic topos in which the idea of the desertum is recreated.

In reality, however, a number of allusions made in the written sources, in addition to the (possible) material evidence, would seem to point towards the presence of a well developed settlement which preceded the advent of the monks. Indeed, upon their arrival, they found a preexisting church in which miracles (virtutes) are carried out ${ }^{28}$. This is a sign of the already Christian character of the valley, in a location that was made attractive not only by the fertility of the soil and the presence of mineral springs, but also by its advantageous positioning on a number of important route ways. It was situated where the road between Piacenza (and the Po plain) and Genoa (and by extension the Mediterranean) met the roads that passed through the Apennine valleys and connected Pavia and Milan with central Italy ${ }^{29}$. This favourable positioning, moreover, was even more important during the early Lombard period, due to its proximity to the frontiers with the Byzantine world. While this border should not to be seen as a defined line, it represented a significant presence in the geopolitics of the Apennine region, as it

\footnotetext{
${ }^{24}$ F. Bougard and G. Noyé, "Chronique. Squillace», Mélanges de l'École Française de Rome, Moyen Âge 98, 1986, 1195-1212; A. Coscarella, «Il monastero "vivariense sive castellense" e l'edificio triconco di Stalettì (CZ): da Pierre Courcelle a oggi», in A. Coscarella, P. De Santis (eds.), Martiri, santi, patroni: per una archeologia della devozione, Proceedings of the $10^{\text {th }}$ National Conference on Christian Archaeology (Arcavacata di Rende, 15-18 September 2010), Arcavacata di Rende: Università della Calabria, 2012, 299-315, with previous bibliography.

${ }^{25}$ Marazzi, Le città, pp. 151-152.

${ }^{26}$ A. Zironi, Il monastero longobardo di Bobbio, Crocevia di uomini, manoscritti e culture, Spoleto: Fondazione CISAM 2004, part. 1-21.

${ }^{27}$ Ionas, Vitae Columbani discipulorumque eius, I, 30, ed. B. Krusch, in MGH, SSRM, IV, Hannoverae et Lipsiae, $1902,107$.

${ }^{28}$ Ibid.

${ }^{29}$ F.G. Nuvolone (ed.), La fondazione di Bobbio nello sviluppo delle comunicazioni tra Langobardia e Toscana nel Medioevo, Proceedings of the International Congress (Bobbio, 1-2 October 1999), Bobbio: Amici di Archivum Bobiense, 2000; E. Destefanis, Il monastero di Bobbio in età altomedievale, Firenze: All'insegna del Giglio, 2002.
} 
extended across the other side of the mountain ridge in the Ligurian territory not yet occupied by the Lombards ${ }^{30}$.

Beyond a number of reliquaries (including one Irish example dating to the seventh century) and various terracotta eulogiae originating from the western Mediterranean - not to mention the notable collection of ampulae from the Holy Land, which demonstrate the key role played by the monastery as a centre on the paths of the international pilgrimage ${ }^{31}$ - very little material evidence for the earliest phase of the monastery's existence has been found to date, apart from some small pieces of information contained in the text of Jonas. The latter refers to an enclosing wall (septa), the stables for the pack animals and, perhaps, rooms where activities such as book binding and shoe repairing were carried out ${ }^{32}$.

As much as the Columbanian experience at Bobbio marked a turning point in Italian monasticism, it was destined to remain a somewhat isolated case, at least until the late seventh century when, under the leadership of King Perctarit (671-688) and later his successor Cunipert (688-700), the Lombard monarchy embraced the catholic faith. A process of strong consolidation of the Church was then initiated throughout the Italian peninsula, which included the restoration of the diocesan seats and the foundation of monasteries ${ }^{33}$. The main protagonists of this latter aspect are the sovereigns themselves who between the late seventh and eighth century, along with local dukes and members of the lay and ecclesiastical aristocracy, were actively founding new monasteries, not only in the capital Pavia, but throughout Italian territory.

From a structural point of view, with the possible exception of the findings on the female monastery of Cairate - which have only recently been published and have yet to undergo an indepth review ${ }^{34}$-, the material remains are quite scarce for the period encompassing the end of the seventh century and the first half of the eighth. In general terms, even in the Lombard period, the reuse of pre-existing structures would seem to have been a very common phenomenon, as can be seen at sites from Brescia (S. Salvatore) to Farfa and S. Vincenzo al Volturno, to name but a few examples. The mechanisms of this reuse, however, demonstrate a noticeable diversification, with implications for the interpretation of the use of buildings, starting from the question of whether the sites in which the monasteries were founded were in continuous use (albeit in a different form) up until the moment of establishment, or whether they had been completely abandoned $^{35}$. Another factor is the nature of the contexts that are reused, with greater or lesser transformations: in the case of Brescia, for exemple, the monastery founded by Desiderius (duke and subsequently King of the Lombards) in the 750s sits on a pre-existing settlement dating to the $7^{\text {th }}$ century, which possessed a church as well as factory buildings arranged around quadrangular open areas. This configuration, later adopted by Desiderius' foundation, could be

${ }^{30}$ R. Conversi, E. Destefanis, «Bobbio e il territorio piacentino tra VI e VII secolo: questioni aperte e nuove riflessioni alla luce dei dati archeologici», Archeologia Medievale, 41, 2014, 289-294, with previous bibliography.

${ }^{31}$ E. Destefanis, «Il monastero di Bobbio sulle vie del pellegrinaggio altomedievale: fonti scritte e dati materiali», in F. Benozzo, M. Montesano (eds.), Pellegrinaggi e monachesimo celtico. Dall'Irlanda alle sponde del Mediterraneo, Proceedings of the Conference (Genova, 14 October 2010), Studi Celtici, numero speciale 2010, Alessandria: Edizioni dell'Orso, 2010 [2011], 59-108.

${ }^{32}$ Ionas, Vitae Columbani, II, 5, 117.

${ }^{33}$ C. Azzara, L'ideologia del potere regio nel Papato altomedievale, Spoleto: CISAM, 1997, 168-169.

${ }^{34}$ V. Mariotti (ed.), Un monastero nei secoli. Santa Maria Assunta di Cairate. Scavi e ricerche, Mantova: SAP, 2014.

${ }^{35}$ Destefanis, *Archeologia dei monasteri altomedievali», 351-359. 
interpreted as either the centre of a curtis regia or even the early nucleus of an already extant monastery ${ }^{36}$.

The Brescian monastery, notable for its particular layout, and specifically the presence of three quadrangular cortiles, defined by rectangular buildings which housed the rooms in which the daily life of the resident nuns was carried out, represents an essential case study for understanding the problem of the organisation of monastic space. Indeed, even into the Carolingian period, some monasteries seem not to have adopted the cloister formula in the strictest sense, i.e. one central area bordered by porticoes galleries around which the monastic buildings are arranged ${ }^{37}$.

The religious buildings themselves do not present any typology that could be specifically identified as 'monastic', neither in terms of the dimensions - which vary according to the makeup of the community or more importantly in relation to the needs of the individual monastery nor in their layout. In many cases, particularly in Northern Italy, the model of the aisleless church ending with three apses (Dreiapsidensaalkirche) has been documented (S. Felice and S. Maria Teodote in Pavia, S. Maria d'Aurona in Milano, S. Salvatore in Brescia, S. Salvatore in Sirmione, in addition to other examples): these features, however, should not, it must be said, be considered as particular to monasteries. Instead they often represent a choice linked to a high ranking official, the expression of a royal or aristocratic foundation ${ }^{38}$.

In most cases local building traditions played a determining role in the architectonic choices, as can be seen for example in the case of Novalesa. ${ }^{39}$ It sits along the route which leads to the pass of Moncenisio in the western Alps and the quadrangular apse of its abbatial church and chapels pertains to a style quite common throughout the whole alpine region. This foundation represents one of the most significant examples of an early medieval monastic complex in the Italian context, given the presence of a number of religious buildings which, all lying within the area of the monastery, have different but complementary roles to the abbatial church - from funerary functions, intended not only for the community but also for lay people who had the privilege of being buried on monastic ground (see also Brescia, Sesto al Reghena ${ }^{40}$, and S. Vincenzo al Volturno $)^{41}$ to those which offered spiritual assistance to pilgrims and worshipers who arrived at the monastery (also at Brescia and other sites) ${ }^{42}$. In other cases the monasteries organised space for pastoral care outside of the area strictly defined by the enclosing wall; this

\footnotetext{
${ }^{36}$ G.P. Brogiolo and F. Morandini (eds.), Dalla corte regia al monastero di San Salvatore-Santa Giulia di Brescia, Mantova: SAP, 2014.

${ }^{37}$ P.F. Pistilli, sub voce "Chiostro», in Enciclopedia dell'Arte Medievale, IV, Roma: Istituto della Enciclopedia ItalianaTreccani, 1993, 694-718.

38 S. Lomartire, "Riflessioni sulla diffusione del tipo "Dreiapsidensaalkirche" nell'architettura lombarda dell'altomedioevo", Hortus Artium Medievalium, 9, 2003, 417-432.

${ }^{39}$ G. Cantino Wataghin, «L'établissement et l'histoire de l'abbaye de Novalaise», in Lauwers, Monastères, 255-288.

${ }^{40}$ G.C. Menis, A. Tilatti (eds.), L'abbazia di Santa Maria di Sesto fra archeologia e storia, Fiume Veneto: GEAPprint, 1999.

${ }^{41}$ Most recently: F. Marazzi, Le città, pp. 173-175, with previous bibliography. About the funerary spaces in the monasteries see also G. Cantino Wataghin, E. Destefanis, «Les espaces funéraires dans les ensembles monastiques du Haut Moyen Âge», in Lauwers, Monastères, 503-554.

${ }^{42}$ E. Destefanis, «Le monastère face aux läques au haut Moyen Âge : lieux de culte secondaires et accueil aux limites de l'espace monastique dans le contexte italien", Bulletin du Centre d'études Médiévales d'Auxerre, hors-série n ${ }^{\circ} 8$, 2015 (http://cem.revues.org/13599).
} 
space was intended for the community which built up around the monastery, forming what was to become a genuine monastic burgh. A number of these settlements are documented as early as the Early Medieval period (Bobbio, Borgo S. Dalmazzo) ${ }^{43}$, where a plebs (a baptismal church) developed, ensuring the necessary pastoral care was delivered, as can be seen in the case at Nonantola, where the excavation of the Church of S. Michele has brought to light the medieval footprint of the settlement ${ }^{44}$.

The situation documented above, particularly in relation to the Lombard period, precedes the changes that came about during the Carolingian period, which sees a continuity without any hiatus. It must be said, however, that in a number of cases, such as Bobbio, Farfa and S. Vincenzo al Volturno, thanks to imperial support and the development of a European wide network of connections, these sites became exceptional cases in the Italian panorama. For the time being, the most precise archaeological data for the Italian context undoubtedly come from S. Vincenzo al Volturno, where construction between the end of the eighth and start of the ninth century ${ }^{45}$ of a monumental abbatial church, situated at the heart of the monastery, along with the living, production, hospitality and funerary memory compounds ${ }^{46}$, represents without a doubt the most tangible evidence of the grandeur reached, equal to the great abbeys on the other side of the Alps.

\section{France}

The earliest monasteries begin to appear in Gaul slightly later than in Italy, during the second half of the $4^{\text {th }}$ and first half of the $5^{\text {th }}$ century, in the regions of the west, Provence, the Rhone valley and the Jura Mountains. Numbering no more than a dozen in the earliest phase, they grew from 22 at the start of the $6^{\text {th }}$ century to 115 at the start of the $8^{\text {th }}$ century, spread across the whole of the country. ${ }^{47}$

Founded around 361A.D, Ligugé, is traditionally considered 'the first monastery in France'. ${ }^{48}$ Sulpicius Severus tells us that Hilarius, Bishop of Poitiers, placed a hermitage close to the city in the name of Saint Martin. ${ }^{49}$ Archaeological investigation has shown that the monastery was founded in the ruins of an antique villa, characteristic of the Late Empire domains

\footnotetext{
${ }^{43}$ E. Destefanis, «Monasteri, poli devozionali e abitato: riflessioni sui "borghi monastici” di età medievale dell'Italia settentrionale, tra fonti scritte e strutture materiali», in P. De Vingo (ed.) Le archeologie di Marilli. Miscellanea di studi in ricordo di Maria Maddalena Negro Ponzi, Alessandria, forth.

${ }^{44}$ S. Gelichi, «La pieve di San Michele: storia di una Chiesa e storia degli scavi», in S. Gelichi and M. Librenti (eds.), Nonantola 4. L'abbazia e le sue chiese, Firenze: All'Insegna del Giglio, 2013, 93-16.

${ }^{45}$ F. Marazzi, La "basilica maior" di San Vincenzo al Volturno (scavi 2000-2007), Cerro al Volturno: Volturnia Edizioni, 2014.

${ }^{46}$ Marazzi, Le città, 248-253.

${ }^{47}$ C. Sapin, "L'archéologie des premiers monastères en France... ", op. cit., p. 84.

${ }^{48}$ C. Heitz, "La France pré-romane. Archéologie et architecture religieuse du Haut Moyen Âge, du IV siècle à l'an Mille ", Paris, 1987, p. 71.

${ }^{49}$ B. Boissavit-Camus, "Les édifices cultuels de l'abbaye de Saint-Martin de Ligugé (Vienne) ", Wisigoths et Francs autour de la bataille de Vouillé (507). Recherches récentes sur le haut Moyen Âge dans le Centre-Ouest de la France, Saint-Germain-en-Laye, 2010, p. 215-235.
} 
found throughout South-West Gaul. The earliest building on the site (possibly a cellar) was constructed in an antique pool, perhaps within the lifetime of Saint Martin, and was followed in the same location by the earliest church, which continued in use up to its extension in the $10^{\text {th }}$ $11^{\text {th }}$ centuries. This reading of the archaeology, which we also find on other sites, brings us to the thorny subject of the transition from villa to monastery in Late Antique Gaul, a process which is still not fully understood. ${ }^{50}$

The foundation was followed in 371 by the establishment of Marmoutier, once again linked to Saint Martin and located on the right bank of the Loire river, just two kilometres above the castrum of Tours. Archaeological research has shown that the site where the gothic abbatial church now stands was the site of continual occupation from the $1^{\text {st }}$ or $2^{\text {nd }}$ century A.D. onwards, with a network of terraces and the construction of well-built, ornately decorated structures. As has already been noted for a number of Italian sites, particularly Brescia, the nature of this earliest occupation is difficult to define; it may have been linked to a stopping post, a suburban villa or a small settlement. While the structures would be remodelled numerous times down to the $11^{\text {th }} \mathrm{C}$., the antique structures were originally transformed into a place of worship from the $5^{\text {th }}$ century onwards. The cliff face is dotted with numerous grottos, additions which are very difficult to date due to their regular refurbishments. Sulpicius Severus claims that Saint Martin lived in a wooden cell, even though the monks had carved their grottos into the cliff side in the vein of the Egyptian monasteries. The wide range of religious buildings and funerary areas attested in the $11^{\text {th }}$ century may date as far back as the first centuries of the monastery, however, the remains to be proven by the archaeological research.

During the first quarter of the 5th century a second sphere of monasticism sprang up, this time in Provence, as exemplified by the foundations of Lérins between 400-410 A.D., under the direction of Honoratus, followed by John Cassian's foundation at Marseille in around 415 . Little is still known about the layout of the monastery of Lérins on Île Saint-Honorat prior to the Romanesque period, such as the origin and chronology of the network of seven places of worship, which not only delimited the space on the island but also contributed to its sacralisation. ${ }^{51}$ However, the most recent excavations have allowed us to gain an insight into the organisation of the monastery in Late Antiquity. ${ }^{52}$ The first phase, dated to the 5 th century, corresponds with a single nave church opening onto an apse; this small building, probably a secondary religious building, reserved for prayers, was bounded on the south by what could be interpreted as one or more attached hermit cells. These results are reminiscent of the two small conjoined rooms found at the abbey of the Holy Cross at Poitiers, interpreted as the cell and the

\footnotetext{
${ }^{50}$ On this see: Roberto Alciati, "And the villa became a monastery: Sulpicius Severus' community of Primuliacum", Western Monasticism ante litteram. The Spaces of Monastic Observance in Late Antiquity and the Early Middle Ages, H. Dey, E. Fentress, Brepols, 2011, p. 85-98; N. Reveyron, «Forma monasterii. Essai sur l'organisation de l'espace monastique comme mise en forme de l'identité ecclésiologique ", Hortus artium medievalium, vol. 20/2, ZagrebMotovun, 2014, p. 439-447.

${ }^{51}$ R.-M. Dessi, M. Lauwers, « Désert, Eglise, île sainte. Lérins et la sanctification des îles monastiques de l'Antiquité à la fin du Moyen Âge ", in, Y. Codou, M. Lauwers (éd.), Lérins, une île sainte de l'Antiquité au Moyen Âge, Turhout, 2009, p. 277-279.

${ }^{52}$ Y. Codou, "Aux origines du monachisme : le dossier de Saint-Honorat de Lérins ", L'empreinte chrétienne en Gaule (de la fin du IVe au début du VIIIe siècle), M. Gaillard (textes réunis par), Turhout, 2014, p. 291-310.
} 
oratory of saint Radegund dating to the middle of the $6^{\text {th }}$ century. ${ }^{53}$ The second phase, dated to between the end of the $6^{\text {th }}$ and beginning of the $7^{\text {th }}$ century, saw the 'cells' of Lérins replaced by an annexe of the oratory, which assumed a commemorative and funerary function, as demonstrated by the discovery of a tomb whose architecture is dedicated to the carrying out of libations. However, many questions remain about the origins of the other secondary chapels, communal buildings as well as the links between Île Saint-Honorat and the nearby island of Sainte-Marguerite. The latter, also occupied in Late Antiquity, would seem to have been the site of significant construction, with a maritime villa most likely built there during the Roman Imperial period. ${ }^{54}$ Another site with a possible monastic function is the building, fortified during Late Antiquity, perched on an escarpment of the nearby Île de Porquerolles, which evokes the image of cells and brings to mind the writings of John Cassian on the hermitages of the Hyres Islands. ${ }^{55}$ In relation to Marseilles itself, while it is generally accepted that John Cassian was the founder of two urban monasteries ${ }^{56}$, one male and one female, their exact location remains unknown, and there remains much debate surrounding the links that have been made with the abbey of Saint Victor, located on the site of the eponymous saint's tomb. ${ }^{57}$

The foundation of a monastery in relation to a venerated tomb, often of earlier date, is not an unusual practice; the presence of a community assures the protection of the saint's grave and controls the access of pilgrims to the site, although it is still difficult to determine whether the community consists of group of ordinary clerics or monks from the very beginning. A wellknown example of this is the Abbey of Saint-Germain at Auxerre, where the early Christian oratory of Germanus' villa is gradually incorporated into the basilica between the $6^{\text {th }}$ and the $8^{\text {th }}$ centuries (when the monastic community became established there), before being converted into a crypt in the $9^{\text {th }}$ century. ${ }^{58}$ At St Quentin the mausoleum of the Carolingian abbey is erected around the Late Antique tomb of the martyr. ${ }^{59}$ The same process is also found at St Maurice d'Agaune (Switzerland) where the monastic community, attested as early as 515 , is focussed on a succession of six churches erected on the site of a funerary space and the mausoleum of an

\footnotetext{
${ }^{53}$ Y. Labande-Mailfert, "Poitiers. Abbaye Sainte-Croix », Premiers monuments chrétiens de la Gaule, vol. 2, Paris, 1996, p. 284-289.

${ }^{54}$ A. Arnaud, "Les îles de Lérins, Sainte-Marguerite et Saint-Honorat (Cannes, Alpes-Maritimes), in, M. Pasqulini, P. Arnaud, C. Varaldo (dir.), Des îles côte à côte. Histoire du peuplement des îles de l'Antiquité au Moyen Âge (Provence, Alpes-Maritimes, Ligurie, Toscane), Bulletin Archéologique de Provence, supplément 1, Aix-en-Provence, 2003, p. 175-190.

${ }^{55}$ J.-C. Tréglia, «L'occupation des îles d'Hyères durant l'Antiquité tardive ", ibid., p. 127-132.

56 J.-P. Weiss, "Jean Cassien et le monachisme provençal ", in Saint-Victor de Marseille. Études archéologiques et historiques. Actes du colloque Saint-Victor, Marseille, 18-20 novembre 2004, M. Fixot et J.-P. Pelletier (éd.), BAT 13, Turhout, 2009, p. 179-185.

${ }^{57}$ M. Fixot, "Saint-Victor, à propos d'un livre récent", Marseille. Trames et paysages urbains de Gyptis au Roi René, Actes du colloque de Marseille 1999, Études Massaliètes 7, Aix-en-Provence, 2001, p. 235-254; M. Fixot et J.-P. Pelletier, Saint-Victor de Marseille. Études archéologiques et historique... op. cit. p. 6.

${ }^{58}$ C. Sapin (sous la dir.), Archéologie et architecture d'un site monastique. 10 ans de recherche à l'abbaye Saint-Germain d'Auxerre (Xe-XXe siècles), Paris, 2000, 493 p.

${ }^{59}$ M. Gaillard et C. Sapin, "Autour de la tombe de saint Quentin : histoire et archéologie d'un culte (milieu IV ${ }^{\text {e }}$ début VIII s.), L'empreinte chrétienne en Gaule... op. cit., p. 271-288.
} 
important figure from the second quarter of the $4^{\text {th }}$ century. ${ }^{60}$ To these examples one could add the royal Abbey of Saint Denis, whose origins lie in the construction of a mausoleum, or an oratory, on the tomb of a martyred saint, between the $4^{\text {th }}$ and $5^{\text {th }}$ centuries. ${ }^{61}$

Notwithstanding the case of St Victor, it is undoubtedly under the influence of Cassien that Castor of Apt founded his monastery in 426. Although its location has not been identified, an attempt has been made to link it to the remains excavated at Saint-Estève de Ménerbes. ${ }^{62}$ This site, of which few comparisons are known, is organised around a central court (perhaps an atrium), which contains a quatrefoil basin. Along the eastern side of the court is what would appear to be a funerary basilica, flanked by a portico which links it to funerary areas on the northern and southern sides. The identification of the features as those of a monastery is mainly based on the fact that the anthropological study of the skeletal remains identified only male remains. More than any other site, the complex of Saint-Estève poses questions relating to the criteria used to distinguish monasteries from generic 'ecclesiastical sites' for which we possess no written records dating to Late Antiquity and the Early Medieval period. ${ }^{63}$

Staying in Provence, at the monastery of Saint-Jean, founded by Caesarius in the town of Arles at the beginning of the 6th century, the archaeological remains have transformed our understanding of the site: the excavation revealed a vast basilica dating to the first half of the $6^{\text {th }}$ century and used up until the $9^{\text {th }}$ century, provoking a rereading of the religious topography of both the town and the quarter in which the building stood. ${ }^{64}$ As a result it would appear that the remains traditionally associated with the monastery of Caesarius ${ }^{65}$ were more likely linked to the early Christian Episcopal complex. In light of this it could be argued that in order to discover remains related to the monastery it is necessary to investigate elsewhere, perhaps to the north of the Cathedral of Saint-Etienne, although still within the walls of the town. ${ }^{66}$

The historiography on the subject holds that the 'monastic ideal' spread first from Provence up the Rhone valley and subsequently on to the Jura Mountains. ${ }^{67}$ One of the Late Antique foundations of Vienne, the abbey of Saint-André-le-haut, founded around 543 in a

60 A. Antonini, "Le site archéologique de l'abbaye ", L'abbaye de Saint-Maurice d'Agaune, Archéothéma 36, septembre-octobre 2014, p. 24-31.

${ }_{61}$ P. Van Ossel, "Les premiers temps de Saint-Denis", Saint-Denis de sainte Geneviève à Suger Dossiers d'archéologie n²97, Dijon, 2004, p. 6-13.

${ }^{62}$ Y. Codou, "Sur les monastères, des éclairages archéologiques nouveaux ", in L'Antiquité tardive en Provence (IV $V I^{e}$ siècle). Naissance d'une chrétienté, p. 134-135.

${ }^{63}$ See the article by Brook's Hedstrom and Dey also on this topic.

${ }^{64}$ M. Heijmans, "Le monument chrétien hors norme de l'enclos Saint-Césaire d'Arles ", in L'Antiquité tardive en Provence ... op. cit., p. 173-179.

${ }^{65}$ Among the many sources on this see : P. A. Février, "Arles. Monastère Saint-Césaire ", dans N. Duval (dir.), Premiers monuments chrétiens de la Gaule, vol. 1, Paris, 1995, p. 121-122.

${ }^{66} \mathrm{M}$. Heijmans, "À propos de la mise à jour de la Topographie chrétienne des cités de la Gaule: réflexions sur le cas d'Arles ", L'empreinte chrétienne en Gaule... op. cit., p. 151-171.

${ }^{67}$ A. Dubreucq, "Lérins et la Burgondie dans le haut Moyen Âge ", in Lérins, une île sainte de l'Antiquité au haut Moyen Âge, Y. Codou et M. Lauwers (textes réunis par), Turnhout, 2009, p. 195-227. 
corner of the reduced Late Antique walls of the city, has been the site of excavations since $2008 .{ }^{68}$ The excavation of the abbatial buildings has revealed a small apsed building (a mausoleum or church perhaps) which maintains - or develops - a memorial function down to the $9^{\text {th }}-10^{\text {th }}$ century. Stratigraphically, this building relates to the earliest monastery. The same is the case for the remains of artisans quarters discovered below the gallery of the Romanesque cloister. At Lyon, the monastery of the Île Barbe, recorded from the early $5^{\text {th }}$ century, has recently been the subject of a reappraisal. ${ }^{69}$ This research has allowed the excavator to define the monastic topography, which to a certain degree calls to mind the situation at Lérins, with its network of secondary cult sites. During the Romanesque period three buildings are erected to structure the religious space around the abbatial church of Saint-Martin, in effect creating a cloistral square. There are strong indications of an early origin for the latter. One feature which undoubtedly has an early origin is the church of Saint Andre, at the eastern end of the island, where excavation has revealed the remains of a building with a funerary function (mausoleum/church) with sarcophagi dating to the $6^{\text {th }}$ century. ${ }^{70}$ It was most likely at the Île Barbe that Romanus, the first of the Jura Fathers and founder of Condat (modern Saint-Claude, founded 430-435), Lauconne (SaintLupicin) and Balme (Saint-Romain-de-Roche), was educated. At the earliest of these sites, Condat, archaeological test trenches in the former abbey (now the cathedral) as well as in the former abbatial palace have allowed us to question once again the motif of the retreat into the desert, as it would appear, based on the ceramic artefacts, that the site of the foundation had already been occupied during the Roman Imperial period, although the exact nature of this occupation remains unclear (stopping post? Rural farm?). ${ }^{71}$ We know almost nothing about the earliest monastery, apart from the remains of two apses found in the choir of the cathedral, one built on top of the other, dating to before the $11^{\text {th }}$ century. Two post build constructions, partially identified in the lower layers of the former abbatial dwellings and stratigraphically earlier than the year 1000, could also be dated to the first decades of the monastery and would seem to recall the description of the foundation in the Vita Patrum Jurensium. ${ }^{72}$ At Saint-Lupicin, a small Late Antique funerary monument - not containing any bones - that was found in the Romanesque church, has been interpreted as the tomb of the founder. ${ }^{73}$

\footnotetext{
${ }^{68}$ A. Baud, N. Nimmegeers et A. Flammin, «L'abbaye de Saint-André-le-haut à Vienne. Origine et développement d'un monastère de moniales ", in L'origine des sites monastiques : confrontation entre la terminologie ... op. cit., (http://cem.revues.org/14485; DOI : 10.4000/cem.14485)

${ }^{69} \mathrm{C}$. Gaillard, L'abbaye de l'île-Barbe à Lyon (Ve-XIII siècles). Archéologie et topographie d'une fondation monastique insulaire, Thèse de doctorat soutenue à l'université Lyon Lumière II le 9 mars 2016 sous la direction de N. Reveyron, 3 vol., $496+127+182$ p.

${ }^{70}$ C. Gaillard, "Étude archéologique de l'église Saint-André (monastère de l'île-Barbe, Lyon) ", Hortus Artium Medievalium, 20/2, Zagreb, 2013, p. 311-322.

${ }^{71}$ S. Bully, "Famille d'églises et circulations : le cas de l'abbaye de Saint-Claude (Jura) du Ve au XVIII siècle ", Actes du colloque de Nantua de novembre 2006, Espace ecclésial et liturgie au Moyen Âge, Lyon, 2010, p. 75-89 ; S. Bully, "Archéologie des premiers monastères dans le Centre-Est de la France. Conditions d'implantation et de diffusion, topographie historique et organisation", Bulletin du Centre d'Études Médiévales d'Auxerre, 13, Auxerre, 2009, p. $257-$ 290 (http://cem.revues.org/index11085.html.)

${ }^{72}$ F. Martine, Vie des Pères du Jura, Éd. du Cerf, Sources chrétiennes 142, Paris, 1968, nouvelle édition 2004.

${ }^{73}$ S. Bully, M. Caušević-Bully, A. Bully, "Coffrage de bois et coffrage de pierre du Ve s. : la tombe présumée de saint Lupicin (Jura)", Le bois dans l'architecture et l'aménagement de la tombe : quelles approches? Actes de la table-ronde d'Auxerre 15-17 octobre 2009, sous la dir. de F. Carré et F. Henrion, tome XXIII des mémoires publiés par l'AFAM, Saint-Germain-en-Laye, 2012 , p. 117-122.
} 
According to the historiography on the subject, ${ }^{74}$ the monastery of Romainmôtier (Switzerland) was also one of the foundations of the Jura Fathers, something which would seem to be supported by the archaeology. ${ }^{75}$ The extensive excavations of the site show that the first monks established themselves in a small Late Antique foundation, possibly an artisans workshop, reusing two wooden framed buildings. Following this, a single aisled church with an apse bordered by two annexes was built and dedicated to Saint-Pierre. It is replaced in the $7^{\text {th }}-8^{\text {th }}$ century by a larger building, with the same plan but with the addition of an eastern annex. At the same time the church doubled in size on the southern side, where a second religious building with a quadrangular choir was built, and the older buildings were replaced by a stone structure. The evolution of the latter is complex, however, the presence of a sophisticated baths area mean that its function is not fully understood - is it an infirmary, the abbots quarters, a lay palace? The early medieval monastery, therefore, presents as an ensemble formed by two parallel churches with conventional buildings placed at an angle to them, thus forming the basis of a future cloister.

The multiplication of religious buildings into a family of two or three churches (in some cases more) would seem to be one of the paradigms of monasteries in Late Antique and Early Medieval Gaul. ${ }^{76}$ However there remain many unanswered questions relating to their origins and respective functions. ${ }^{77}$ Research carried out at Aniane since 2011 has shed light on an establishment founded in the last decades of the $8^{\text {th }}$ century and which is thought to have 'ensured the triumph of the Benedictine Rule and of the ceonbitic form of Frankish monasticism' ${ }^{78}$ It is in the context of this reform that we see the emergence of a new organisation around a cloistral square bordered by a single sanctuary that fulfils all of the necessary functions, along the lines of the model plan of Saint-Gall. ${ }^{79}$ However, at Aniane itself the pre-existing multifarious organisation persists, with the foundation of the first Basilica, dedicated to the Virgin Mary, followed in 782 by the addition of the church of Christ the Saviour 30 meters further away. Between these two churches a third structure was erected (perhaps dedicated to

\footnotetext{
${ }^{74}$ On this see : J. D. Morerod, Romainmôtier, histoire de l'abbaye, dir., Lausanne, 2001.

${ }^{75}$ A detailed account of the archaeological results is currently in preparation by Peter Eggenberger ; for a summary see: P. Eggenberger et J. Sarott, "Romainmôtier (Suisse), un monastère au passé millénaire", in Cluny et ses influences en Europe, Dossiers d'Archéologie HS 19, 2010, p. 48-53.

${ }^{76}$ J. Hubert, J. Porcher, W. F. Volbach, L'Europe des invasions. L'univers des formes, Paris, 1967, p. 64 ; Y. Codou, "Églises multiples et identité monastique dans la Provence médiévale », in, Monastères et espace social.. op. cit., p. 586-610.

${ }^{77}$ As is the case, for example, at the abbey of Jumieges, formed by two principal churches and two secondary oritoiries known from the textual sources (J. Le Maho, «Le monastère de Jumièges (France) aux temps mérovingiens (VII ${ }^{e}-\mathrm{VIII} \mathrm{e}^{e}$ siècle). Le témoignage des textes et de l'archéologie ", Hortus artium medievalium, vol. 9, ZagrebMotovun, 2003, p. 315-322) or even the Abbey of Saint Claude where, thanks to the written sources, we can reconstruct an image of a family of churces from the 6th-7th centuries formed by a double church parallell to the abbatial church (S. Bully, «Famille d'églises et circulations ... op. cit. p. 79-85).

${ }^{78} \mathrm{~L}$. Schneider, "Une fondation multiple, un monastère pluriel. Les contextes topographiques de la genèse du monastère d'Aniane d'après l'archéologie et la vie de saint Benoît (fin VIIIe-IXe s.) ", L'origine des sites monastiques : confrontation..., op. cit. (http://cem.revues.org/14481; DOI : 10.4000/cem.14481)

${ }^{79}$ On the origins of the cloister see : Ch. Sapin, «De la cour au cloître carolingien ", in, Le cloitre roman. Les cahiers de Saint-Michel de Cuxa, Actes des XLVIe Journées romanes de Cuxa, 7-12 juillet 2014, Codalet, 2015, p. 21-34.
} 
Saint Marie Madeleine) prior to the middle of the $12^{\text {th }}$ century, while a fourth church, SaintJean, appeared $250 \mathrm{~m}$ from the monastic centre. The latter figures as one of the gateways to the medieval village walls - although this is not to assume that it held the same role in the early medieval period - and is associated with a funerary space from the second third of the $9^{\text {th }}$ century. On looking at the monastery today one can barely make out the organisation which would prevail at the monastery of Benedict himself at Inden. ${ }^{80}$ This is also the case at the contemporary monastery of Landevennec, which developed out of a single sanctuary, simply doubling the oratory/mausoleum of the founder. ${ }^{81}$

At Môtiers (Switzerland), excavations on a foundation attested in the textual sources from only 1093, have demonstrated the existence of a church of Saint Peter as early as the $6^{\text {th }} / 7^{\text {th }}$ century, followed by a second, Notre Dame, placed alongside it in the $8^{\text {th }} / 9^{\text {th }}$ century. ${ }^{82}$ On a completely different scale, Agaune also possesses two religious buildings, but here they are laid out in a line due to the physical topography of the site, as well as the presence of a baptismal complex and the palace of the lay abbot ${ }^{83}$ or of the bishop which was preserved on the southern side of the churches. ${ }^{84}$ A similar linear organisation also prevails at the Abbey of Saint-Denis, where between the $7^{\text {th }}$ and beginning of the $9^{\text {th }}$ centuries four religious buildings connected by a long portico formed the northern limit of the atrium, or parvis, of the Dionysian basilica ${ }^{85}$. The funerary function of a 'rosary chain of churches' is, therefore, extremely significant, perhaps even an essential and determining feature. As we shall see, the place of the dead is equally central at Luxeuil, although there the family of churches has its origins in an ecclesiastical complex which predates the monastery. In other cases, the funerary function would seem to be limited to particular monuments. The excavations carried out at the Saint-Mont have allowed for the identification of at least two early medieval buildings from the seven religious buildings mentioned in the, mostly later, textual sources. ${ }^{86}$ The first, Saint-Pierre, a simple, rectangular construction more than likely housed no more than one sarcophagus. On the other hand, a second building identified a few dozen metres to the south, is notable for the presence of around 80 formae type tombs (pre-constructed rectangular niches which were regularly reused) ${ }^{87}$ While such a high number of these tombs is exceptional, this burial form may have been specific to religious communities and bears similarities to the Merovingian funerary churches at Saint-

\footnotetext{
${ }^{80}$ Ibid., p. 32-33.

${ }^{81}$ A. Bardel, «L'abbaye Saint-Gwénolé de Landevennec », Archéologie médiévale, t. XXI, Paris, 1991, p. 51-101.

${ }^{82}$ J. Bujard, "Aux origines du prieuré Saint-Pierre de Vautravers. Complications monastiques et vallonnières ", Complication neuchâteloises, histoire, tradition, patrimoine, E. Hertz et F. Wobmann (sous la dir.), Neuchâtel, 2014, p. 30-37.

${ }^{83}$ On the question of lay abbots seeI. Rosé et de J.-P. Devroey in this volume.

${ }^{84}$ A. Antonini, "Le site archéologique de l'abbaye ... ", op. cit. p. 24-31.

${ }^{85}$ P. Perrin, M. Wyss, "La nécropole du haut Moyen Âge. Du quartier de la basilique et son cadre architectural ", Saint-denis de sainte Geneviève à Suger, Dossiers d'archéologie n²97, Dijon, 2004, p. 38-49; M. Wyss (dir.), Atlas historique de Saint-Denis. Des origines au XVIII siècle, Paris, 1996, (DAF 59).

${ }^{86}$ C. Kraemer, T. Chenal, "Pour une archéologie du Romarici mons, ou le Saint-Mont revisité (commune de SaintAmé - Vosges) ", Rencontres Transvogiennes, 4, 2014, 57-80 ; S. Bully et al., "Autour de Luxeuil : état des recherches sur les monastères d'Annegray, de Fontaine et du Saint-Mont ", Le Pays lorrain, Nancy, 2016, à paraître.

${ }^{87}$ S. Bully, "Un dispositif funéraire spécifique : les formae. État de la question et nouvelles découvertes ", Hortus Artium Medievalium, 20/2, Zagreb, 2014, p. 480-488.
} 
Gertrude (phase 2) and the abbey of Nivelles (Belgium). ${ }^{88}$ At the abbey of Manglieu, two religious buildings mentioned in the Life of Saint Bonnet, written just after 700 A.D., and confirmed through archaeological investigation are present within the area of the cloister: NotreDame was built on the site of an oratory of the domain of bishop Genest which was granted to the community, while Saint-Sebastien (an apostle according to the Vita) may have also been built on a building of the domain or an earlier central plan structure (perhaps a mausoleum). ${ }^{89} \mathrm{We}$ will conclude this brief synthesis of sites with the female monastery at Hamage, founded in the second quarter of the $7^{\text {th }}$ century. ${ }^{90}$ This is one of the rare examples of an early medieval French site which has benefitted from archaeological research carried out over a long period. During the first decades of the site the community possessed only a single church, dedicated to Saints Peter and Paul, which was situated outside of the main enclosure and was where the first generations of the community were buried. The wooden structure was rebuilt numerous times up until the $12^{\text {th }}$ century, even though a second church dedicated to Sainte-Marie had been erected in around 700 A.D., this time in the interior of the enclosure. The church of Saint Marie was also used for burials, primarily for women, although there are number of male burials also. The two religious buildings were laid out parallel to each other, a few dozen metres apart. Here the layout, in its relation with the enclosure (or enclosures), is still difficult to interpret given the restrictions related to access that were associated with a community of nuns.

These enclosures have been identified archaeologically as a series of perpendicular ditches reinforced on the interior by a palisade of planks held in place by posts. The main enclosure, which has an irregular rectangular form, ${ }^{91}$ surrounds the church of St Marie, the quotidian buildings of the community - a question that will be returned to later - and perhaps also areas of craft production (writing tablets, bronze, glass). ${ }^{92}$ The remains at Hamage are exceptional, especially given the fact that there are very few monastic enclosures known from Late Antiquity and the Early Medieval period. One could point to the fortified wall at the Abbey of Landévennec, dated to the end of the $8^{\text {th }}$ century and formed of two courses of very large blocks which encase and internal body; it would seem to have been built on top of an earlier, narrower, drystone structure. ${ }^{93}$ Elsewhere, at Romainmôtier, an enclosure was identified on the southern side of the monastery, where it incorporated a small stream of the Nozon, which was possibly reenforced by a dyke wall..$^{94}$

\footnotetext{
${ }^{88}$ F. Chantinne et P. Mignot, "La collégiale Sainte-Gertrude de Nivelles. Réexamen du dossier archéologique ", Hortus artium medievalium, vol. 20/2, Zagreb-Motovun, 2014, p. 513-519.

${ }^{89} \mathrm{D}$. Martinez, "Les premiers monastères d'Auvergne à la lumière de la documentation textuelle et archéologique $\left(\mathrm{V}^{\mathrm{e}}-\mathrm{X}^{\mathrm{e}}\right.$ siècle) : état de la question", in L'origine des sites monastiques ... op. cit. BUCEMA Hors Série 10, Auxerre (http://cem.revues.org/14484 ; DOI : 10.4000/cem.14484).

${ }^{90}$ E. Louis, "Une église monastique du haut Moyen Âge dans le Nord de la France : le cas d'Hamage ", L'empreinte chrétienne en Gaule ... op. cit., p. 357-385

${ }^{91}$ E. Louis, "Espaces monastiques sacrés et profanes à Hamage (Nord), VII ${ }^{\mathrm{e}}-\mathrm{IX}^{\mathrm{e}}$ siècles ", in, Monastères et espace social..., op. cit., p. 435-472.

${ }^{2}$ E. Louis, "Les indices d'artisanat dans et autour du monastère d'Hamage (Nord), VII ${ }^{\mathrm{e}}$-IX ${ }^{\mathrm{e}}$ siècle ", Au seuil du cloître : la présence des lä̈s..., op. cit., p. 215-231 (http://cem.revues.org/13684)

${ }^{93}$ A. Bardel, "L'abbaye Saint-Gwénolé de Landevennec », ... op. cit., p. 51-101.

${ }^{94}$ P. Eggenberger et J. Sarott, "Romainmôtier (Suisse),... op. cit., p. 48-53.
} 
Romainmôtier is a perfect illustration of the 'monastic currents' evident in the west during the first millennium. Originally founded by the Jura Fathers, strongly influenced by the monasteries found in the area of Provence and further afield in the Late Antique East, the establishment was 're-founded' in around 642 by one of the main monasteries to come out of the 'Irish renewal' on the continent; Luxeuil. ${ }^{95}$

The monasteries of Annegray and Luxeuil, founded by the Irish monk Columbanus in the last decade of the 6th century, have been the subject of a new wave of research over the past ten years. ${ }^{96}$ At Annegray, site of Columbanus' first foundation, a landscape archaeological study combined with results from excavation and geophysical prospection, would seem to suggest that the site had previously been occupied by a Gallo-Roman sanctuary. ${ }^{97}$ The place chosen for the foundation was also located close to a route-way, although it has not been possible thus far to identify any structural remains of the Early Medieval phase of the monastery. ${ }^{98}$ It is, however, becoming clear that the foundation of the monastery of Luxeuil shortly thereafter formed part of a political strategy of constructing a territory on the limits of both dioceses and kingdoms, as evidenced by the choice of an antique settlement founded at the confluence of a number of routeways for the establishment of the new community. Luxovium boasted a therapeutic baths sanctuary which was still visible in the $7^{\text {th }}$ century and may have also had other natural resources such as salt. The image, evoked by the hagiographical account of Jonas of Bobbio, of a retreat into the desert, therefore, loses some of its credibility. This has been challenged by the archaeological results, which demonstrate that the Gallo-roman town, located within a castrum, was home to a Christian community from Late Antiquity. ${ }^{99}$ Recent excavations carried out on the church of St. Martin have shown that the sector of the town in which it was situated was abandoned in the Roman period, before being reoccupied by a Late Antique necropolis. On the site of this necropolis, in around the year 500, a mausoleum or a funerary enclosure is augmented to form the huge funerary basilica of St. Martin, laid out in three aisles that open on a quadrangular apse and two funerary annexes. This extramural basilica, completely occupied by sarcophagi, becomes part of the monastery upon its foundation. Subsequently, in around 600 A.D., a chevet crypt is added, which becomes the location of the tomb of the Abbot Valbert in

95 G. Coutaz, "Romainmôtier ou la succession de deux vagues de l'élan missionnaire (V $\mathrm{V}^{\mathrm{e}}-\mathrm{VII} \mathrm{I}^{\mathrm{e}}$ siècles) ", in Romainmôtier. Histoire de l'abbaye, J.-D. Morerod (dir.), Bibliothèque historique vaudoise $\mathrm{n}^{\circ} 120$, Lausanne, 2001 , p. 25-38.

${ }^{96}$ S. Bully et C. Sapin, «Les monastères en Europe occidentale (ve-xe siècle). Topographie et structures des premiers établissements en Franche-Comté et en Bourgogne. Projet collectif de recherche [PCR] ", Bulletin du centre d'études médiévales d'Auxerre BUCEMA 15, 2011 (http://cem.revues.org/11948); For a synthesis of the research see : S. Bully, sous la dir., Colomban et l'abbaye de Luxeuil au cour de l'Europe du haut Moyen Âge, Archéologie en Franche-Comté $\mathrm{n}^{\circ}$ 5, Besançon, 2015, $76 \mathrm{p}$.

${ }^{97}$ E. Marron, In His Silvis Silere : The Monastic Site of Annegray - Studies in a Columbanian Landscape, National University of Ireland, Galway, September 2012, 182 p.

${ }^{98}$ E. Marron, S. Bully, Recent Archaeological Work on the Site of the Columbanian Monastery of Annegray (HauteSaône), Ch. Kraemer et J. Koch (ss la dir.), Vivre dans la montagne vosgienne au Moyen Âge, Actes du colloque de Gérardmer-Munster (30 août-1er septembre 2012), Presses universitaires de Nancy, Nancy, à paraître.

${ }^{99}$ S. Bully, A. Bully et M. Čaušević-Bully avec la coll. de L. Fiocchi, « Les origines du monastère de Luxeuil (HauteSaône) d'après les récentes recherches archéologiques ", L'empreinte chrétienne en Gaule (de la fin du IVe au début du VIII siècle), Turhout, 2014, p. 311-355. 
670. Throughout the $7^{\text {th }}$ and the beginning of the $8^{\text {th }}$ centuries an ad sanctos monastic necropolis develops around the apse of the church of St. Martin. At the same time, monastic inhumations are being made in a second church, possibly dedicated to St Mary, immediately to the north of the abbatial church of St Peter, of which we know nothing at this time. The church of St Mary has only been identified through test trenches. Dating to the $5^{\text {th }}$ century, it also predates the monastery and may have formed part of a double church organisation along with the abbatial church of St. Pierre. The result of these investigations is that the monastic topography of Luxeuil is inherited from an early Christian ecclesiastical conglomeration, the exact nature of which is still unknown. There is evidence for what would appear Merovingian monastic building constructed in the remains of a vast Gallo-Roman structure, found in the courtyard of the gothic cloister. The presence of a monumental, most likely public, antique building may have influenced the choice of location of the monastery within the town. ${ }^{100}$ At both Annegray and Luxeuil there have been no indications to date of any structure that are explicitly indicative of an 'Irish' influence in terms of the topography of the sites.

This is not the case at Hamage, mentioned above, where the excavation revealed a number of sub circular huts, dating to the second half of the $7^{\text {th }}$ century and tentatively compared to contemporary dwellings found in Britain and Ireland. ${ }^{101}$ Towards the end of the $7^{\text {th }}$ century, alongside these cells and perpendicular to the church of Saint Mary, a large wooden building was constructed. The numerous hearths within the structure, combined with a clear series of subdivisions, would seem to indicate personal spaces, although goods were stored centrally. A large room on the southern end of the building had a communal function. This building was replaced by a new wooden structure in the $8^{\text {th }}$ century, this time parallel to the church. The new three aisled building contained a dozen small rooms (cells?) surrounding three central, communal rooms. In addition, the building boasts numerous hearths, latrines and an external oven. The archaeological remains discovered on this site provide a genuine synthesis for the evolution of the sites in which monastic life took place, with a gradual communalisation of space, which reaches its climax with the construction of a cloistral square in the $9^{\text {th }}$ century. The excavations carried out at the Abbey of Saint-Cybard at Angoulême also revealed a communal building dating to the end of the $6^{\text {th }}$ century, consisting of a long hall along which at a later date, in the $9^{\text {th }}$ or 10 century, small rooms, interpreted as cells, were placed. ${ }^{102}$ Another example of an early medieval communal building built on the remains of a late antique structure was revealed within the cloister of the Abbaye-aux-Dames de Saintes. ${ }^{103}$ The building is organised around a large central space, boasting a large hearth to which at least four other rooms are connected, suggesting that there was a system of heating similar to a hypocaust. Such a subdivision and hierarchy of space,

\footnotetext{
${ }^{100}$ Ibid., p. 316-317 et 355 ;

${ }^{101}$ E. Louis, "Sorores ac fratres in Hamatico degentes. Naissance, évolution et disparition d'une abbaye au Haut Moyen Âge : Hamage (France, Nord)", De la Meuse à l'Ardenne, 29, 1999, p. 23.

102 B. Boissavit-Camus, "Saint-Cybard : l'invention d'un lieu (VI'-XI ${ }^{\mathrm{e}}$ siècles)", Saint-Cybard. De l'abbaye au CNBDI. Histoire d'un site, Angoulème, p. 17-20, Réédition numérique 2004, http://www.alienor.org/publications/bibliotheque-saint-cybard/PDF/Saint-Cybard.pdf

${ }_{103}$ C. Vernou, "Vestiges archéologiques du haut Moyen Âge à l'Abbaye-aux-Dames de saintes (fouilles de 1986 à 1988) ", Monastères entre Loire et Charente, C. Treffort et P. Brudy (sous la dir.), Rennes, 2014, p. 219-234.
} 
as well as the presence of home comforts, has led to comparisons with certain buildings represented on the model plan of St. Gall, dating to the first quarter of the $9^{\text {th }}$ century. At the Saint Mont, the excavations carried out to the north of the church of St Peter have revealed a large building with at least two aisles, one of which was perhaps a portico which led from the living quarters to the religeous buildings. The monastic settlement would seem to have been built on the remains of a Late Antique site (possibly a castrum). ${ }^{104}$ More recently, excavations carried out on the high altitude site of Château-sur-Salins have revealed a complex dating to the $6^{\text {th }}$ century consisting of a church and a building located on the site of an earlier fortified space. ${ }^{105}$ The single aisled church, surrounded by a portico, opens onto a quadrangular courtyard surrounded by lateral annexes. The nave of the church is filled with formae type tombs. Located immediately to the west of the church, the building is divided into three rooms. In the absence of textual references to a religious site on the hilltop, an interpretation based solely on the building style of the complex and a number of its characteristics, would lead us to assume that it had a monastic function. One such characteristic is the analysis of the faunal remains from food waste on the site, which show an overrepresentation of fowl, fish and pig bones. This is also the case at Baume-les-Messieurs, where excavations in the choir of the Romanesque abbatial church in 2011 revealed the north-west angle of an $8^{\text {th }}$ century masonry building, which went through four successive phases up until its demolition prior to the construction of the abbatial church at the turn of the millennium. ${ }^{106}$ The remains of hearths, ceramic artefacts and a very large quantity of faunal remains would suggest that the area was the location of the monastic kitchen, or perhaps kitchen annexes associated with the infirmary.

\section{Conclusion}

In order to conclude this brief panorama of sites which takes in the monastic landscapes of Italy and France between the $4^{\text {th }}$ and the $8^{\text {th }}$ centuries, it is necessary to make a number of points. It is generally apparent that the Late Antique communities do not seem to have been very structured, which in the case of Italy may explain their disappearance when faced with the significant changes throughout the $6^{\text {th }}$ century, with first the Gothic wars and the subsequent arrival of the Lombards. Following the establishment of Bobbio, at the beginning of the $7^{\text {th }}$ century, monastic foundations begin to grow in number again during the last quarter of the century thanks to favourable conditions, such as the conversion of the Lombard monarchy to the orthodox Catholicism. In France, on the other hand, one might consider that the early institutionalisation of monasteries ensured their longevity.

\footnotetext{
${ }^{104}$ C. Kraemer, "Du Castrum Habendum au Monasterium Habendum: le Saint-Mont et ses relations avec le peuplement de la Moselotte et de la haute vallée de la Moselle ", in L'Austrasie. Sociétés, économies, territoires, christianisation. Actes des XXVIe journées internationales d'archéologie mérovingienne, J. Guillaume et E. Peytreman (sous la dir.), Nancy, 2008, p. 205-219.

${ }^{105}$ Château-sur-Salins et Pretin : sept millénaires d'occupation. Archéologie dans le Jura, D. Billoin et P. Gandel (sous la dir.), Besançon, 2014, p. 12-19.

${ }^{106}$ S. Bully et al., Le "monastère des reculées » au haut Moyen Âge : avancées de la recherche archéologique sur Balma (Baume-les-Messieurs, Jura), in La mémoire des pierres. Mélanges d'archéologie, d'art et d'histoire en l'honneur de Christian Sapin, Bibliothèque de l'Antiquité tardive, Turnhout, 2016 p. 241-254.
} 
By engaging in a dialogue with the written sources, archaeology allows for a reconsideration of the conditions and the mechanisms of the foundation of many sites, in many cases nuancing, in some cases challenging the motif of the foundation in the desert portrayed by the hagiographical literature. Frequently we find that monasteries were founded in areas that were already inhabited and on residential sites, however, it can be difficult to determine whether there was a continuity of occupation on many sites, and as such how to interpret the role and function of antique elements within the early monastic architecture and topography. A more detailed understanding would allow us to gain insights into the motivations which led to the choice of certain sites (such as, in the case of Italy, the villa of Nero at Subiaco, or even the sanctuary of Appolo at Monte Cassini). ${ }^{107}$ However this observation brings with it new questions in relation to the legal situation of the site and the buildings that the monks occupy concerning the authorisations - for commons - donations, transfers and spoliations. ${ }^{108}$ Although the role of the bishops is important (notably Gregory the Great in Italy), numerous foundations originate from the private initiatives of the traditional roman aristocracy, as well as Burgundian, Frankish and Lombard aristocracy and royal families. Monastic foundations are often very closely connected to the territory in which they are established, from an economic as well as social and institutional perspective. Without going into too much detail here, we would point to the similarities between the distant monasteries of Luxeuil and Bobbio, particularly in terms of the political conditions and the choice of sites, as has been argued elsewhere. ${ }^{109}$ This interpretation demonstrates that it is necessary to analyse these sites on a number of levels, starting with the monument itself, followed by the complex in which it sits and subsequently the physical, cultural and political landscape in which it is founded.

In relation to the living quarters of the earliest monasteries, both in Italy and in France, it is incredibly difficult to identify a model, given the fact that there is a great variety visible in the excavated evidence, in contrast to the common language found in the written sources. While not wanting to reject it outright, the question of 'imported models', be they oriental (Kellia, grottoes etc.) or Irish (roundhouses/huts), must be dealt with very carefully, considering the scarcity of the evidence. It must also be considered within the context of the edifying nature of the textual sources (vitae) or, more prosaically, the reality of contemporary, local, vernacular construction methods. A communalisation of space would seem to have taken place between Late Antiquity and the Early Medieval period, with the emergence of structures which would appear to be replacing individual cells, however in order to build up a clearer picture it is necessary for work to be carried out on the living spaces in these communities. ${ }^{110} \mathrm{~A}$ new approach would eventually

\footnotetext{
${ }^{107}$ M.G. Fiore Cavaliere, "Monachesimo prebenedettino e benedettino: note di topografia monastica», in Ead. (éd.), Sublaqueum-Subiaco, Roma 1995, p. 13-24.

${ }^{109}$ This topic is covered in more detail in the forthcoming articles : E. Destefanis, R. Conversi et A. Zironi, « Bobbio dans son contexte : un monastère et son territoire " and S. Bully, E. Marron, "Aux pieds des Vosges, les monastères d'Annegray et de Luxeuil : conditions de fondations et premiers éléments de topographie ", Colomban et son influence. Moines et monastères du haut Moyen Age en Europe, Actes du colloque de Luxeuil-les-bains (16-20 septembre 2015), à paraître.

${ }^{110}$ On this see : Au seuil du cloitre... op. cit.
} 
emerge in the normalisation of this communal lifestyle with the adoption of the cloister model, which enjoyed particular success in the West from the Carolingian period onwards. ${ }^{111}$ For the earlier period, however, the case of the monastery of Brescia, organised around a number of 'courtyards', is an exception to the rule.

Although it is certainly the case that there is a higher degree of organisation in the early medieval period compared to Late Antiquity, there a numerous charters, particularly in the Lombard Kingdom, which still make reference to monasteries that are in effect nothing more than small groups, in some cases of the same family, often female, who live a life of retreat in a simple house where they care for the poor. ${ }^{112}$ Unfortunately, given the fact that such buildings bear no clearly visible signs of organisation or codified structure, these 'monasteries' remain invisible from an archaeological perspective. On another scale, but still difficult to detect archaeologically, is the question of 'double monasteries' that emerge in France during the Merovingian period - perhaps through Irish influence - where a community of men and a community of women existed in the same location. ${ }^{113}$ The evidence would seem to suggest that these sites were organised around multiple cloisters and religious buildings.

Finally, a major difference between France and Italy is undoubtedly the use of 'families' of churches within a monastery, which does not emerge in Italy until the $8^{\text {th }}$ century and even then in a much less structured manner than in Gaul, although it must be said that the idea of a principal church surrounded by a number of 'satellite chapels' is not unheard of (as in the case of Novalesse, for example). A further question related to these sites that requires much more archaeological research in the future is the question of the presence of baptisteries within the monasteries linked to the function of pilgrimage and perhaps even for the cura animarum - such as at Tours, Saint Maurice d'Agaune or on the plan of St Gall. ${ }^{114}$

\footnotetext{
${ }^{111}$ Parmi les nombreux essais relatif à la question de la constitution du cloître : Ch. Sapin, « De la cour au cloître carolingien ", in, Le cloître roman. Les cahiers de Saint-Michel de Cuxa, Actes des XLVI Journées romanes de Cuxa, 7-12 juillet 2014, Codalet, 2015, p. 21-34.

${ }^{112}$ On house ascetics and consecrated women, see the article by Magnani in this volume.

${ }^{113}$ A.-M. Helvétius, "L'organisation des monastères féminins à l'époque mérovingienne », In : Melville G. \& Müller A., Female vita religiosa between Late Antiquity and the High Middle Ages. Berlin-Münster, 2011, p. 151-169. See the article by Beach \& Juganaru in this volume

${ }^{114}$ S. Uggé, "I battisteri in ambito monastico nella tarda antichità e nell'alto medievo ", in L'edificio battesimale in Italia, D. Gandolfi (sous la dir.), Firenze, 2001, p. 385-403.
} 
Bully, Sébastien. "Archéologie des premiers monastères dans le Centre-Est de la France. Conditions d'implantation et de diffusion, topographie historique et organisation," BUCEMA 13 (2009): 257-290 (http://cem.revues.org/index11085.html.).

Bully, Sébastien. "Famille d'églises et circulations: le cas de l'abbaye de Saint-Claude (Jura) du V au XVIII siècle." In Espace ecclésial et liturgie au Moyen Âge. Actes du colloque de Nantua de novembre 2006, ed. A. Baud, 75-89. Lyon, 2010.

Bully, Sébastien, Aurélia Bully et Morana Čaušević-Bully (with the collaboration of Laurent Fiocchi."Les origines du monastère de Luxeuil (Haute-Saône) d'après les récentes recherches archéologiques.” In Gaillard (2014), 311-355.

Bully, Sébastien and Christian Sapin, eds. Au seuil du cloître : la présence des laïcs (hôtellerie, bâtiments d'accueil, activités artisanales et de services) entre le Ve et le XIIe s., Actes des 3èmes journées d'études monastiques, Vézelay, 27-28 juin 2013, BUCEMA, Hors Série 8 (2015). (http://journals.openedition.org/cem/13574)

Bully, Sébastien and Christian Sapin, eds. L'origine des sites monastiques : confrontation entre la terminologie des sources textuelles et les données archéologiques, Actes des 4èmes journées d'études monastiques, Baume-les-Messieurs, 4-5 septembre 2014. BUCEMA, Hors Série 10 (2016). (http://journals.openedition.org/cem/14463)

Cantino Wataghin, Gisella. "Moines et monastères en Italie à l'arrivée de Colomban: quelques données entre archéologie et histoire." BUCEMA 20.2 (2016) (http://cem.revues.org/14521).

Cantino Wataghin, Gisella and Eleonora Destefanis. "Les espaces funéraires dans les ensembles monastiques du Haut Moyen Âge.” In Lauwers (2015), 503-554.

Codou, Yann. “Aux origines du monachisme: le dossier de Saint-Honorat de Lérins.” In Gaillard (2014), 291-310.

Codou, Yann. “Églises multiples et identité monastique dans la Provence médiévale.” In Lauwers (2015), 586-610.

Codou, Yann and Michel Lauwers, eds. Lérins, une île sainte de l'Antiquité au Moyen Âge. Turnhout, 2009.

De Rubeis, Flavia and Federico Marazzi, eds. Monasteri in Europa occidentale (secoli VIII-XI): topografia e strutture. Proceedings of the International Conference (Castel San Vincenzo, September 23rd-26th 2004). Rome, 2008.

Delouis, Olivier and Maria Mossakowska-Gaubert, eds. La vie quotidienne des moines en Orient et en Occident (IV ${ }^{e}-V I^{e}$ siècle). Le Caire, 2015.

Destefanis, Eleonora. "Archeologia dei monasteri altomedievali tra acquisizioni raggiunte e nuove prospettive di ricerca." Post-Classical Archaeologies 1 (2011): 349-382.

Dey, Hendrick and Elizabeth Fentress, eds. Western Monasticism ante litteram. The spaces of monastic observance in Late Antiquity and the Early Middle Ages. Turnhout, 2011.

Duval, Noël, ed. Premiers monuments chrétiens de la Gaule, 2 vols. Paris, 1996.

Ermini Pani, Letizia, ed. Committenza, scelte insediative e organizzazione patrimoniale nel medioevo. Proceedings of the International Conference (Tergu, September 15th-17th 2006). Spoleto, 2007.

Ermini Pani, Letizia, ed. Le valli dei monaci. Proceedings of the International Conference (RomaSubiaco, May 17th-19th 2010). Spoleto, 2012. 
Ermini Pani, Letizia, ed. Teoria e practica del lavoro nel monachesimo altomedievale. Proceedings of the International Conference (Roma-Subiaco, June 7-9 2013). Spoleto, 2015.

Ermini Pani, Letizia, ed. Gli spazi della vita comunitaria. Proceedings of the International Conference (Roma-Subiaco, June, 8th-10th 2015). Spoleto, 2016.

Gaillard, Michèle, ed. L'empreinte chrétienne en Gaule (de la fin du IVe au début du VIII siècle). Turnhout, 2014.

Helvétius, Anne-Marie. "L'organisation des monastères féminins à l'époque mérovingienne," in Female vita religiosa between Late Antiquity and the High Middle Ages, ed. Gert Melville and A. Müller, 151-169. Münster, 2011.

Jenal, Georg. Italia ascetica atque monastica. Das Asketen- und Mönchtum in Italien von den Anfängen bis zur Zeit der Langobarden (ca. 150/250-604). Stuttgart, 1995.

Lauwers, Michel, ed. Monastères et espace social. Genèse et transformations d'un système de lieux dans l'Occident médiéval. Turnhout, 2015.

Louis, Etienne. "Une église monastique du haut Moyen Âge dans le Nord de la France : le cas d'Hamage." In Gaillard (2014), 357-385.

Louis, Etienne. "Les indices d'artisanat dans et autour du monastère d'Hamage (Nord), VII ${ }^{\mathrm{e}}-\mathrm{IX}^{\mathrm{e}}$ siècle," in Bully and Sapin (2015), 215-231 (http://cem.revues.org/13684)

Marazzi, Federico. Le città dei monaci. Storia degli spazi che avvicinano a Dio. Milano, 2015.

Marron, Emmet. In His Silvis Silere: The Monastic Site of Annegray - Studies in a Columbanian Landscape, National University of Ireland, Galway, September 2012, 182 p.

Martinez, Damien. "Les premiers monastères d'Auvergne à la lumière de la documentation textuelle et archéologique ( $\mathrm{V}^{\mathrm{e}}-\mathrm{X}^{\mathrm{e}}$ siècle): état de la question." In Bully and Sapin (2016) (http://cem.revues.org/14484)

Reveyron, Nicolas. "Forma monasterii. Essai sur l'organisation de l'espace monastique comme mise en forme de l'identité ecclésiologique." HAM 20/2 (2014) : 439-447.

Sapin, Christian, ed. Archéologie et architecture d'un site monastique. 10 ans de recherche à l'abbaye Saint-Germain d'Auxerre (Xe-XXe siècles). Paris, 2000.

Sapin, Christian. "De la cour au cloître carolingien." In Le cloître roman. Les cahiers de SaintMichel de Cuxa, Actes des XLVIe Journées romanes de Cuxa, 7-12 juillet 2014, XLVI (2015), 21-34.

Schneider, Laurent. "Une fondation multiple, un monastère pluriel. Les contextes topographiques de la genèse du monastère d'Aniane d'après l'archéologie et la vie de saint Benoît (fin VIIIe-IXe s.)." In Bully and Sapin (2016) (http://cem.revues.org/14481)

Somma, Maria Carla, ed. Cantieri e maestranze nell'Italia medievale. Proceedings of the International Conference (Chieti-San Salvo, May 16th-18th 2008). Spoleto, 2010.

Stasolla, Francesca Romana. "Il monachesimo in Italia dalle origini a Gregorio Magno: modalità insediative, architetture, organizzazione topografica e spaziale." In Monachesimi d'Oriente e d'Occidente nell'Alto Medioevo, LXIV Settimana di Studio (Spoleto, March 31st - April 6th 2016), 321-354. Spoleto, 2017

Uggé, Sofia. "Lieux, espaces et topographie des monastères de l'Antiquité tardive et du haut Moyen Âge : réflexions à propos des règles monastiques." In Lauwers (2015), 15-42. 
